\title{
Increasing Mothers' Knowledge of Infant and Young Child Feeding through Booklets in Banggai Regency, Central Sulawesi Province, Indonesia
}

\author{
Yulianus Sudarman H Melangka ${ }^{1 *}$, Masudin Masudin ${ }^{1}$, Iwan Iwan ${ }^{1}$, Sri Musriniawati Hasan ${ }^{1}$ (D), Taqwin Sahe ${ }^{2}$ (D) \\ ${ }^{1}$ Departement of Nursing, Poltekkes Kemenkes Palu, Palu, Indonesia; ${ }^{2}$ Departement of Midwifery, Poltekkes Kemenkes Palu, \\ Palu, Indonesia
}

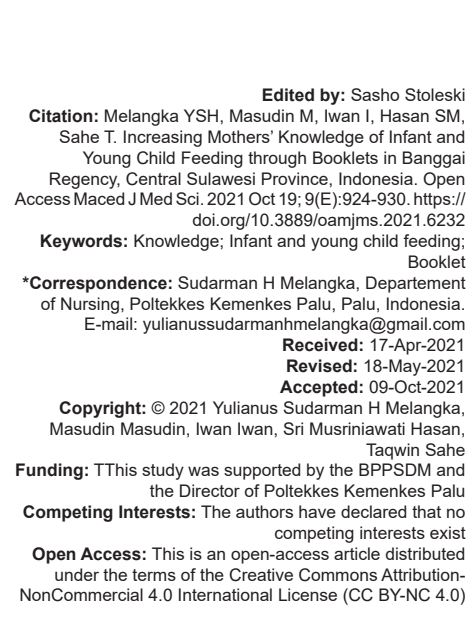

\section{Introduction}

Stunting, defined as height measurements below minus two standard deviations of the World Health Organization (WHO) growth reference median, reflects chronic exposure to a deficient environment and undernutrition [1]. Stunting in children under 5 years could lead to impaired physical development and have a long-term effect on cognitive development, educational performance and economic productivity in adulthood and on maternal reproductive outcomes. This linear growth deficit continues to deteriorate till the age of five due to sustained exposure to unpleasant environmentally modifiable factors related to feeding, infections, and psychosocial care. The continued decline in linear growth observed in the first 5 years of life may cause severe irreversible physical and neurocognitive damage that accompanies stunted growth and pose a major threat to human development [2]. In certain communities within countries, wasting can be 9 times higher in children under the age of five, stunting 4 times higher, and overweight and obesity 3 times higher in children under the age of five. There is a clear link between infant and young child feeding (IYCF) habits and household factors. Breastfeeding is less common for children in wealthier households, urban areas, or with a more educated mother up to the age of 1 or 2 years. For children in the poorest households, however, rates of solid food introduction and minimum diet diversity are significantly lower [3]. A dynamic interplay of infant, maternal, household, environmental, and socioeconomic factors affecting nutritional intake influences optimal growth and development in early childhood [4]. Study showed that stunting prevalence has positive associations to mother with $\geq 2$ children [5], family size [6], and living in medium and large family size [7], and multiple births [8]. At the household level, children from families with two or more children under the age of five were found to have a higher risk of stunting [9].

Globally, 20.5 millions of newborns (14.6\%) have a low birth weight, with levels of progress well 
below those required to achieve the 2025 target. Stunting still affects 149.0 millions $(21.9 \%)$ of children under 5 years of age, and wasting affects 49.5 millions $(7.3 \%)$ of children under 5 years of age; progress is far too slow to achieve any of those targets. Notably, Asia is home to more than half of the world's stunted children (81.7 million, 54.8\%). We are also off course to meet the target for overweight in children, with 40.1 million (5.9\%) children under 5 years of age being overweight [3]. The prevalence of child stunting in Indonesia has remained high over the past decade, and at the national level is approximately $37 \%$ [10].

Banggai District in Central Sulawesi Province is known to be one of the areas in the list of 100 priority districts/cities that must be intervened to overcome stunted children or stunting in 2018. Nevertheless, stunting cases are found throughout Central Sulawesi. The prevalence of infants under 5 years of age (toddlers) experiencing stunting due to malnutrition in Central Sulawesi until 2017 is still $30 \%$. Jayabakti Village is the most populous village in Central Sulawesi with a population of around 6000 people/km2, located in the Pagimana archipelago, Banggai Regency. Data for 2019 show that from the ten villages monitored, the Banggai District Health Office recorded 128 children under five who experienced stunting from all villages. Jayabakti Village has the highest prevalence of stunting, namely 53 people (41.4\%). The Stewart Framework suggests IYCF are a direct factor in the causes of stunting [11]. Knowledge is the main aspect in attitude and behavior, especially in terms of IYCF. Prevention of stunting can be achieved with better knowledge of IYCF. Foods from animals are special foods for children. These foods should be eaten every day or as often as possible. To give more energy foods, families can give some extra foods between meals. These extra foods are often called snacks but should not be confused with sweets [12]. A child needs time to get accustomed to the new taste and texture of complementary foods. Give as much as the child will eat with active encouragement. A child needs to learn the skill of eating. Encourage families to start with 2-3 small spoonfuls of food twice a day [12].

Booklet distribution is one of the various educational methods that are usually used and can be applied to a special group, for example, couples of reproductive age. Providing information through writing is a common practice among couples of childbearing age, as is the case with the booklet method. This method utilizes the sense of sight by optimally reading pictorial writing [13]. The most effective media are booklets [14]. Other studies have also shown that the use of booklet in an effort to reduce the prevalence of stunting has been proven effective [14], [15], [16], [17], [18], [19], [20], [21], [22], [23], [24], [25]. In this case, parents are one of the factors that can control early stunting prevention.

This study aims to find out whether the mothers knowledge of infants and young children feeding could be increased through booklets at Banggai Regency of Central of Sulawesi Province.

\section{Methods}

This study is a quasi-experimental nonrandomized study with pre- and post-test only control design. The population of this study was the mothers who had children under 5 years of age residing in Jayabakti Village, Pagimana District, Banggai Regency. Study samples consisted of 40 mothers who were selected accidentally. The study was carried out for 3 months from October to December 2020. The protocol of this study had been approved by the Ethical Committee of Palu Health Polytechnic Ministry of Health (No. LB.01.01/KE/0019/VI/2020).

The intervention included providing booklets once in a month at the local Integrated Health Service Post. Booklets were distributed 3 times within the span of 3 months of the study period. The booklet used is a modified booklet from the IYCF Counseling: An Integrated Course that has been developed by the WHO [12]. Before distributing the booklets, the initial data were collected, and 3 month later the final data were collected again [13]. This method was applied to see the effect of booklet on mothers' knowledge of IYCF for preventing stunting in Central Sulawesi [21].

The mean difference was due to test the differences in pre-test and post-test results of mothers' knowledge regarding their infants and young children feeding using the paired $t$ test. Statistical analysis for the relationship between characteristics of respondents and mothers' knowledge regarding IYCF used the Chisquare test. Hypothesis test was carried out with $95 \%$ confidence level $\alpha=0.05$ using SPSS [21].

\section{Results}

Table 1 shows that respondents aged 15-20 years dominate the study sample (42.5\%), while respondents aged 36-40 years represent only $5 \%$ of the total samples. The similar figure is observed for children's age. Children aged 1 year represent $62.5 \%$ and those aged 5 years represent only $2.5 \%$. In general, majority of the mothers have completed high school $(45 \%)$ and $5.0 \%$ of them have graduated from university. On average, each family has three children $(55.0 \%)$. However, no family has only one child. The maximum number of children is 5 . In general, the respondents' family income is $<586,000$ rupiah. There are only two families of the respondents who have an income of more than Rp. 586,000. 
Table 1: Characteristics of respondents

\begin{tabular}{lll}
\hline Characteristic & $\mathrm{n}$ & $\%$ \\
\hline Mother age (years) & 17 & \\
$15-20$ & 12 & 42.5 \\
$21-25$ & 2 & 30.0 \\
$26-30$ & 7 & 5.0 \\
$31-35$ & 2 & 17.5 \\
$36-40$ & & 5.0 \\
Child age (years) & 25 & 62.5 \\
1 & 4 & 10.0 \\
2 & 8 & 20.0 \\
3 & 2 & 5.0 \\
4 & 1 & 2.5 \\
5 & 10 & 25.0 \\
Mother education & 10 & 25.0 \\
Elementary of School & 18 & 45.0 \\
Junior High School & 2 & 5.0 \\
Senior High School & & \\
Graduate & 7 & 17.5 \\
Number of children in family & 22 & 55.0 \\
2 & 3 & 7.5 \\
3 & 8 & 20.0 \\
4 & & \\
5 & 38 & 95.0 \\
Income family in rupiah & 2 & 5.0 \\
$<586,000$ & & \\
$\geq 586,000$ & &
\end{tabular}

Table 2 shows that the mothers' knowledge of their infants and young children feeding before the intervention has a mean value of 8.88 points. After the distribution of booklet for three months, there was an increase in knowledge of 7.97 points.

Table 2: Comparison of mother knowledge of infant and young child feeding before and after booklets intervention

\begin{tabular}{llll}
\hline Statistic value & Before & After & p-value \\
\hline $\mathrm{N}$ & 40 & 40 & 0.000 \\
Mean & 8.88 & 16.85 & \\
Mean difference (lower-upper) & $8.87(8.53-9.22)$ & $16.85(16.56-17.14)$ & \\
\hline Source: Primary Data, 2020 & & &
\end{tabular}

Table 3 show that the respondents' knowledge regarding feeding is adjusted to the age and nutritional needs of the child. Children aged 1-3 years need

Table 3: Mothers' knowledge of infants and young children feeding after booklets intervention

\begin{tabular}{|c|c|c|c|}
\hline S. No & $\begin{array}{l}\text { Knowledge about infant and young child Feeding after Booklet } \\
\text { Intervention }\end{array}$ & $\mathrm{n}$ & $\%$ \\
\hline 1 & Feeding is adjusted to the age and nutritional needs of the child & 40 & 100 \\
\hline 2 & $\begin{array}{l}\text { Nutrients consist of carbohydrates, protein, fat, vitamins, mineral, } \\
\text { and water }\end{array}$ & 39 & 97.5 \\
\hline 3 & $\begin{array}{l}\text { The body gets energy from types of nutrients, namely, } \\
\text { carbohydrates, proteins and fats }\end{array}$ & 39 & 97.5 \\
\hline 4 & $\begin{array}{l}\text { Food materials that do not contain a lot of carbohydrates are } \\
\text { agars and jelly }\end{array}$ & 25 & 62.5 \\
\hline 5 & Children aged $1-3$ years need $1000 \mathrm{kcal}$ of calories/day & 40 & 100 \\
\hline 6 & $\begin{array}{l}\text { Nutritious and balanced food consisting of staple foods, side } \\
\text { dishes, fruit, milk, and vitamins }\end{array}$ & 40 & 100 \\
\hline 7 & Protein functions to replace damaged body tissue cells & 40 & 100 \\
\hline 8 & Substances that can dissolve Vitamins $\mathrm{A}, \mathrm{D}, \mathrm{E}$, and $\mathrm{K}$ are fat & 40 & 100 \\
\hline 9 & Vegetables and fruits are sources of vitamins and minerals & 36 & 90 \\
\hline 10 & $\begin{array}{l}\text { Food ingredients that contain lots of carotene/pro vitamin A are } \\
\text { papaya, pumpkin, and broccoli }\end{array}$ & 36 & 90 \\
\hline 11 & $\begin{array}{l}\text { Omega- } 3 \text { essential fatty acids that are good for brain development } \\
\text { in children are found in fish oil, nuts, and Vitamin B complex }\end{array}$ & 39 & 97.5 \\
\hline 12 & Ideal body weight for 1 -year-old children is $8 \mathrm{~kg}$ & 40 & 100 \\
\hline 13 & Milk should be given to children under five twice a day & 40 & 100 \\
\hline 14 & $\begin{array}{l}\text { Boiling vegetables for too long will cause the loss of Vitamin B } \\
\text { and Vitamin C }\end{array}$ & 40 & 100 \\
\hline 15 & Yellow, red vegetables, and fruits contain lots of carotene & 38 & 95 \\
\hline 16 & $\begin{array}{l}\text { One way that can be attempted to reduce the loss of water- } \\
\text { soluble vitamins during the food processing is to cook the } \\
\text { ingredients intact and then sliced just before serving }\end{array}$ & 39 & 97.5 \\
\hline 17 & Lack of Vitamin D in children can cause bone and tooth loss & 7 & 17.5 \\
\hline 18 & $\begin{array}{l}\text { Sources of iron can be found in the following food ingredients: } \\
\text { Eggs, liver, and meat }\end{array}$ & 40 & 100 \\
\hline 19 & $\begin{array}{l}\text { Phosphorus is a mineral that plays a very important role in the } \\
\text { growth of bones and teeth }\end{array}$ & 7 & 17.5 \\
\hline 20 & $\begin{array}{l}\text { Lack of protein in children for a long time will cause Marasmus } \\
\text { disease }\end{array}$ & 9 & 22.5 \\
\hline
\end{tabular}

$1000 \mathrm{kcal}$ of calories/day, nutritious and balanced food consisting of staple foods, side dishes, fruit, milk, and vitamins. Proteins play a role in replacing damaged body tissue cells. Substances that can dissolve Vitamins $A, D, E$, and $K$ are fat. Ideal body weight for 1-year-old children is $8 \mathrm{~kg}$. Milk should be given to children under five at least twice a day. Cooking vegetables for too long will cause the loss of Vitamin $B$ and Vitamin C (respondent responses were very good or $100 \%$ true). Iron can be found in the following food ingredients: Eggs, liver, and meat. And then about nutrients consist of carbohydrates, protein, fat, vitamins, mineral, and water, the body gets energy from types of nutrients, namely, carbohydrates, proteins, and fats Omega-3 essential fatty acids that are good for brain development in children are found in fish oil, nuts, and Vitamin B complex. One way that can be attempted to reduce the loss of water-soluble vitamins during the food processing is to cook the ingredients intact and then sliced just before serving (respondent responses were $90-97.5 \%$ true). Yellow, red vegetables, and fruits contain lots of carotene. Vegetables and fruits are sources of vitamins and minerals. Food ingredients that contain lots of carotene/pro Vitamin A are papaya, pumpkin, and broccoli. However, food materials that do not contain a lot of carbohydrates are agar and jelly, lack of protein in children for a long time will cause Marasmus disease. Lack of Vitamin D in children can cause bone and tooth loss. Phosphorus is a mineral that plays a very important role in the growth of bones and teeth (respondent responses were 17.5\%-62.5\% true).

The respondent's knowledge about feeding is adjusted to the age and nutritional needs of the child. Children aged 1-3 years need $1000 \mathrm{kcal}$ of calories/ day. Milk should be given to children under five in 2 a day. Boiling vegetables for too long will cause the loss of Vitamin B and Vitamin C (respondent responses were very good or $100 \%$ true). Omega-3 essential fatty acids that are good for brain development in children are found in fish oil, nuts, and Vitamin B complex. One way that can be done to reduce the loss of watersoluble vitamins during the food processing is to cook the food materials intact and then sliced just before serving (respondent responses were 90-97.5\% true). Lack of protein in children for a long time will cause Marasmus disease. Lack of Vitamin $D$ in children can cause bone and tooth loss. Phosphorus is a mineral that plays an important role (respondent responses were $17.5-62.5 \%$ true).

After the intervention of giving the booklet for 3 months, there was an increase in the knowledge of the mother regarding IYCF. Mother's character which has a significant effect on knowledge is the mother's age factor. The higher the mother's age, the better her knowledge regarding infant and child feeding $p=0.015$ $<0.05$. Factors of children's age, mother's education, number of family members, and household income did 
not have a significant effect on mother's knowledge of IYCF in Banggai, Central Sulawesi (Table 4).

\section{Discussion}

Child stunting reduction is the first of six goals in the global nutrition targets for 2025 and a key indicator in the second sustainable development goal of zero hunger [10] Nutrition education is a component of health education programs, which are defined as a planned initiative in the health sector to improve the actions of people, households, organizations, and communities [26], [27].

The communication strategy contains the basic principles of prioritizing practical steps in its activities. This activity can be carried out through various media according to the existing situation and conditions. Effective activities will produce results, namely, the addition of knowledge and changes in behavior to the target. The use of booklets can increase attention, improve memory/retention of a message/information and to explain facts, procedures, and actions/skills. Retention is the process of remembering and forgetting something, to reach an area that is remembered so that it is sufficient, and then the material with a media book must be read over and over again in a not too long period of time [28].

In the current study, the characteristics of study respondents were focused on maternal age, maternal qualifications, the number of children in the family and household income per month in rupiah units. Respondents between the ages of 15 and 20 represent $42.5 \%$ of the sample, while those between the ages of 36 and 40 represent only $5 \%$. Children as young as 1 year old represent $62.5 \%$ of the total, while children as young as 5 years old represent only $2.5 \%$ of the total. In general, mothers completed a formal study level $(45 \%)$, with $5.0 \%$ of them graduated from university. Each family has three children on average (55.0\%). No family, however, has just one child. The highest children number in one family is five. The respondent's family income is 586,000 rupiah on average. After the intervention of giving the booklet for 3 months, there was an increase in the knowledge of the mother regarding IYCF. The higher the mother's age, the better her knowledge. Factors of children's age and mother's education did not have a significant effect.

Booklet can have an instant effect so that one's knowledge can increase. In addition, factors that can affect a person's level of knowledge are education, age, culture, and economy. Education can affect the learning process so that the higher education a person gets, the easier it will be for that person to get information. Senior High School is the highest level of education for this study respondents. This period is the first step in determining a person to choose and determine his life in the future. Age can affect a person's knowledge because the older the person, the more his perceptive power and mindset will develop, so that the knowledge he gets is getting better. On average, this study subjects were dominated by mothers aged 15-20 years where this period was a period of great curiosity so that it made the mother find out and it would have an impact on her knowledge using a trial and error system. The older a person is, the more mature a person will be to make good decisions in thinking and working. This is a collaboration resulting from experience and mental maturity so as to expand one's knowledge. Tradition (culture) affects knowledge because someone who has a good culture will have good knowledge, but if the social culture is not good then his knowledge will be less good. Family income affects the level of knowledge [20].

Early marriage among girls is a risk factor for early childhood growth and stunting. Study by Efevbera et al. shows that the odds of being off-track for development and being stunted are $25 \%$ and $29 \%$ higher, respectively, for children born to women who married before age 18 compared to those whose mothers married later. Geographic location and primary education, which were conceptualized as contextual factors, explained most of this relationship. Disparities in advanced maternal education and wealth explained child development and stunting, authors say. They conclude that there are intergenerational consequences of girl child marriage on her child's well-being. Study by Pangaribuan et al. show that there was a link between early marriage and underage pregnancy and childhood stunting. The study found that babies of early marriage parents were more vulnerable to growth and developmental disability. The study recommended that the adolescent health-care program and integrated child care surveillance be established to minimize the risk of occurrence [29], [30]. The reduction in infant stunting is still very limited to women and children under 2 years of age. The form of education provided to society needs to be more persuasive to increase action to solve practical problems and improve their health.

The respondent's knowledge about feeding is adjusted to the age and nutritional needs of the child. Children aged 1-3 years need $1000 \mathrm{kcal}$ of calories/ day. Milk should be given to children under five in 2 a day. Boiling vegetables for too long will cause the loss of Vitamin B and Vitamin C (respondent responses were very good or $100 \%$ true). Omega-3 essential fatty acids that are good for brain development in children are found in fish oil, nuts, and Vitamin B complex. One way that can be done to reduce the loss of watersoluble vitamins during the food processing is to cook the food materials intact and then sliced just before serving (respondent responses were 90-97.5\% true). Lack of protein in children for a long time will cause Marasmus disease. Lack of Vitamin D in children can cause bone and tooth loss. Phosphorus is a mineral 
that plays an important role (respondent responses were $17.5 \%-62.5 \%$ true).

Fishermen communities rely on their fish catches and have not utilized the coastal area to carry out other economic activities, so that fishing communities belong to groups of people who are left behind economically, socially, and culturally. In fishing families early marriages are often encountered. The findings of this study show that there were $42.5 \%$ of 15-20 years old mothers; this means that mothers who married at an early age in Jayabakti village were quite high. At an early age their knowledge is still very minimal. This study also shows that the good knowledge of mothers is those who have completed university education, although general high school and junior high school education also have good knowledge with a smaller percentage (100\% vs. $70 \%)$.

Number of children in family, the socioeconomic conditions and nutritional status of parents are the strongest factors correlated with anthropometric failure of children, according more than half of the respondents who have more than three children. The health and well-being of productive mothers in the household needs an understanding of their parental practices and nutritional status. As a consequence, education is required to modify actions to increase maternal and child welfare [5], [6], [7], [31]. Poverty alleviation, women's empowerment, and household feeding services can all be effective methods for reducing childhood malnutrition [32]. Improving modern contraceptive methods utilization to reduce family size is recommended [7]. A study by Utami et al. (2020) showed a significant correlation between family characteristics and nutritional parenting with the occurrence of stunting in children under five in South Jakarta.

Table 4: The relationship between characteristics of respondents and mothers' knowledge regarding infant and young child feeding

\begin{tabular}{|c|c|c|c|c|c|}
\hline \multirow[t]{3}{*}{ Characteristic } & \multicolumn{4}{|c|}{ Booklet } & \multirow[t]{3}{*}{ p-value } \\
\hline & \multicolumn{2}{|c|}{ Good } & \multicolumn{2}{|c|}{ Not good } & \\
\hline & $\mathrm{n}$ & $\%$ & $\mathrm{n}$ & $\%$ & \\
\hline Mother age (years) & & & & & $0.015^{*}$ \\
\hline $15-20$ & 15 & 88.2 & 2 & 11.8 & \\
\hline $21-25$ & 5 & 41.7 & 7 & 58.3 & \\
\hline $26-30$ & 1 & 50.0 & 1 & 50.0 & \\
\hline $31-35$ & 7 & 100.0 & 0 & 0 & \\
\hline $36-40$ & 2 & 100.0 & 0 & 0 & \\
\hline \multicolumn{6}{|l|}{ Child age (years) } \\
\hline 1 & 21 & 84.0 & 4 & 16.0 & 0.395 \\
\hline 2 & 2 & 50.0 & 2 & 50.0 & \\
\hline 3 & 5 & 62.5 & 3 & 37.5 & \\
\hline 4 & 1 & 50.0 & 1 & 50.0 & \\
\hline 5 & 1 & 100 & 0 & 0 & \\
\hline Mother education & & & & & 0.799 \\
\hline Elementary of School & 7 & 70.0 & 3 & 30.0 & \\
\hline Junior High School & 7 & 70.0 & 3 & 30.0 & \\
\hline Senior High School & 14 & 77.8 & 4 & 22.2 & \\
\hline Graduate & 2 & 100 & 0 & 0 & \\
\hline \multicolumn{6}{|c|}{ Number of children in family } \\
\hline 2 & 4 & 57.1 & 3 & 42.9 & 0.605 \\
\hline 3 & 18 & 81.8 & 4 & 18.2 & \\
\hline 4 & 2 & 66.7 & 1 & 33.3 & \\
\hline 5 & 6 & 75.0 & 2 & 25.0 & \\
\hline \multicolumn{6}{|l|}{ Income family in rupiah } \\
\hline$<586,000$ & 29 & 76.3 & 9 & 23.7 & 0.402 \\
\hline$\geq 586,000$ & 1 & 50.0 & 1 & 50.0 & \\
\hline
\end{tabular}

Study by Utami et al. (2020) also showed that families whose incomes were below the regional minimum wage had a 6.625 times greater chance of observing stunting in children under five compared to families whose incomes were above the regional minimum wage with Wald value of 28.148. Socioeconomic factors, especially household income, are the factors that are most responsible for influencing the incidence of stunting in children under five. Multisector and integrated programs are needed to increase household income, knowledge, and family skills to reduce the incidence of stunting in children under two.

Since the younger the age of marriage means the more time to produce, early marriage has an effect on maternal health and the health of the baby later. Stunting has the potential to cause cognitive disorders, motor disorders, body growth problems, increased morbidity, and death in children. Several Indonesian studies have looked into health education, especially nutrition before pregnancy the level of awareness can be influenced by one's proximity to information sources. Information gathered from print media, social media, and health professionals, for example, has an effect on one's awareness. Someone who has access to a number of sources of information would have a greater idea of how to stop stunting [33], [34], [35], [36], [37], [38], [39]. The influence of mother's knowledge about exclusive breastfeeding shows that the influence of mother's knowledge increases through the presentation of interactive lectures using booklet media, while interactive lectures without book media show that maternal knowledge varies.

The role of the media in health promotion is critical, since the message conveyed by the media would be more interesting and understandable. According to Dale's, $20 \%$ of knowledge is remembered solely by listening. However, in this research, the experimental community received booklet, ensuring that the information was conveyed effectively [21].

Formal education is not a determinant of knowledge related to infant and child feeding. Increasing knowledge through booklets is an option for fishing community groups who are far from the city center. Counseling is an integral aspect of feeding a IYCF successfully. Improving child survival and fostering safe growth and development needs optimal IYCF [40]. Knowledge regarding long-term protein deficiency in children that can lead to Marasmus disease, the benefits of Vitamin D and Phosphorus for healthy bones and teeth still need to be well socialized using booklets.

\section{Conclusion}

Mother's knowledge regarding IYCF at Banggai Regency Central of Sulawesi is generally 
good. Knowledge increases after booklets intervention. The mother's experience grows with age. Formal education is not a determinant of knowledge related to infant and child feeding. For fishing community groups based outside of the city center, growing awareness by booklets is an alternative. Long-term protein deficiency in infants, which can lead to Marasmus disease, is wellknown. The value of Vitamin D and phosphorus for solid bones and teeth is also underappreciated.

\section{References}

1. Svefors P, Pervin J, Islam Khan A, Rahman A, Ekström EC, El Arifeen $\mathrm{S}$, et al. Stunting, recovery from stunting and puberty development in the MINIMat cohort, Bangladesh. Acta Paediatr. 2020;109(1):122-33. https://doi.org/10.1111/apa.14929

2. Akombi BJ, Agho KE, Hall JJ, Merom D, Astell-Burt $\mathrm{T}$, Renzaho AM. Stunting and severe stunting among children under-5 years in Nigeria: A multilevel analysis. BMC Pediatr. 2017;17(1):1-16. https://doi.org/10.1186/s12887-016-0770-z PMid:28086835

3. Behrman N. Global Nutrition Report. United Kingdom: North Quay House; 2020.

4. Hafid F, Taqwin T, Linda L, Nasrul N, Ramadhan K, Bohari B. Specific interventions to prevent stunting in children under 2 years after the natural disaster. Open Access Maced J Med Sci. 2021;9:64-9. https://doi.org/10.3889/oamjms.2021.5677

5. da Silva Ferreira H, Albuquerque GT, dos Santos TR, de Lima Barbosa L, Cavalcante AL, Duarte LE, et al. Stunting and overweight among children in Northeast Brazil: Prevalence, trends (1992-2005-2015) and associated risk factors from repeated cross-sectional surveys. BMC Public Health. 2020;20(1):736. https://doi.org/10.1186/s12889-020-08869-1 PMid:32434581

6. Dereje H, Haymanot A, Degefa T. Predictors of child stunting in fitche town, North Shewa zone, Ethiopia. Afr J Food Agric Nutr Dev. 2020;20(3):15992-6012. https://doi.org/10.18697/ ajfand.91.17650

7. Yoseph A, Beyene $\mathrm{H}$. The high prevalence of intestinal parasitic infections is associated with stunting among children aged 6-59 months in Boricha Woreda, Southern Ethiopia: A crosssectional study. BMC Public Health. 2020;20(1):1270. https:// doi.org/10.1186/s12889-020-09377-y

8. Hailu BA, Bogale GG, Beyene J. Spatial heterogeneity and factors influencing stunting and severe stunting among under-5 children in Ethiopia: Spatial and multilevel analysis. Sci Rep. 2020;10(1):16427. https://doi.org/10.1038/ s41598-020-73572-5

PMid:33009463

9. Simelane MS, Chemhaka GB, Zwane E. A multilevel analysis of individual, household and community level factors on stunting among children aged 6-59 months in Eswatini: A secondary analysis of the Eswatini 2010 and 2014 multiple indicator cluster surveys. PLoS One. 2020;15(10):e0241548. https://doi. org/10.1371/journal.pone.0241548

PMid:33125409

10. Beal T, Tumilowicz A, Sutrisna A, Izwardy D, Neufeld LM. A review of child stunting determinants in Indonesia. Matern Child Nutr. 2018;14(4):1-10. https://doi.org/10.1111/mcn.12617 PMid:29770565

11. Prendergast AJ, Humphrey JH. The stunting syndrome in developing countries. Paediatr Int Child Health. 2014;34(4):250-65.

PMid:25310000

12. World Health Organization, UNICEF. Infant and Young Child Feeding Counselling: An Integrated Course. Geneva: World Health Organization, UNICEF; 2006.

13. Ayumar DF, Margawati A, Wijayanti HS. The effect of nutrition education with lecture methods based on Indonesian supporting language (bisindo) and practicals on knowledge, attitudes and nutrition in deaf adolescents with SLB in Semarang. J Nutr Coll. 2019;8(3):146-55. https://doi.org/10.14710/jnc.v8i3.25804

14. Azwar A, Musdalipa M. Media booklet dan leaflet sebagai upaya pencegahan stunting: Kajian literatur (a literature review). Community Fam Gerontol Nurs J. 2020;1(1):29.

15. Ekayani NP, Nurmayasari N, Gumilang I. Antenatal Education with Booklet Media on Knowledge and Readiness of Pregnant Women under the Age of 20 Years. J Inf Kesehat. 2020;18(1):508. https://doi.org/10.31965/infokes.vol18.iss1.311

16. Nna D, Septianingsih N, Pangestu JF. Perbedaan pengetahuan ibu balita sebelum dan sesudah sesudah diberikan penyuluhan tentang stunting melalui media video dan leaflet di wilayah kerja puskesmas Saigon Kecamatan Pontianak timur. J Kebidanan Khatulistiwa. 2020;6(1):180. https://doi.org/10.30602/jkk. v6i1.493

17. Seksaria SA, Sheth MK. Mass media as a means to bring about behavioral changes in infant and young child feeding practices amongst tribal mothers of Chikhli Taluka, Gujarat. Indian J Public Health Res Dev. 2015;6(4):113. https://doi. org/10.5958/0976-5506.2015.00210.7

18. Ifadah LM, Purwaningrum YE, MusI WN. Pengaruh Konseling Gizi Menggunakan Media Booklet Terhadap Peningkatan Pengetahuan MPASI Pada Ibu Balita Stunting Usia 6-24 Bulan. Yogyakarta: Wilayah Kerja Puskesmas Pengasih II Kabupaten Kulon Progo Yogyakarta; 2019. https://doi.org/10.14710/jnc. v3i1.4520

19. Harahap J. Pengaruh Penyuluhan Tentang Asupan Zink dan Fe Dengan Media Booklet Terhadap Sikap Ibu Yang Mempunyai Anak Balita Stunting Yang Pernah Mendapat Cookies Kacang Merah di Desa Kubah Sentang Kecamatan Pantai Labu; 2020. Available from: http://www.ecampus.poltekkes-medan.ac.id. [Last accessed on 2021 Feb 12]. https://doi.org/10.26630/ jk.v10i3.1386

20. Hasanah U, Permadi MR. Pengaruh media booklet terhadap pengetahuan remaja putri mengenai stunting di Kabupaten Probolinggo. HARENA J Gizi. 2020;1(1):2.

21. Salsabela N, Suhartono $E$, Arifin $S$. The effect of booklet media with interactive lecture method on mother's knowledge and intention in giving exclusive breastfeeding in the Sungai ulin public health center working area. Int J Res Publ. 2018;2(1):1-7.

22. Mawarni L, Rahmiwati A. Pengaruh Pendidikan Kesehatan Dengan Media Flipchart Terhadap Pengetahuan Dan Sikap Ibu Tentang Stunting; 2019. Available from: http://www.repository. unsri.ac.id. [Last accessed on 2021 Feb 10]. https://doi. org/10.36743/medikes.v7i1.203

23. Ahmed KY, Agho KE, Page A, Arora A, Ogbo F. Interventions to Improve Infant and Young Child Feeding Practices in Ethiopia: A Systematic Review; 2020. Available from: http://www. researchsquare.com. [Last accessed on 2021 Mar 03]. http:// dx.doi.org/10.1136/bmjopen-2021-048700

24. Agbozo F. Qualitative assessment of counselling on infant and young child feeding provided by community health workers to caregivers at child welfare clinics in Ghana. Int $\mathrm{J}$ Commun Health. 2016;6:97-108.

25. Tice MR. Strengthening Maternal, Infant and Young Child Feeding Training and Education Delivery in Ghana; 2019. Available from: http://www.elischolar.library.yale.edu. [Last accessed on 2021 Mar 03]. 
26. Bukari M, Abubakari MM, Majeed M, Abizari AR, Wemakor A, Atosona A. Effect of maternal growth monitoring knowledge on stunting, wasting and underweight among children 0-18 months in Tamale metropolis of Ghana. BMC Res Notes. 2020;13(1):45. https://doi.org/10.21203/rs.2.16457/v2

PMid:31996253

27. Setia A, Shagti I, Boroa RM, Adi AM, Saleh PA. The effect of family-based nutrition education on the intention of changes in knowledge, attitude, behavior of pregnant women and mothers with toddlers in preventing stunting in Puskesmas Batakte, Kupang Regency, East Nusa Tenggara, Indonesia working area. Pak J Med Heal Sci. 2020;14(3):1001-4.

28. Hafid F, Keperawatan J, Kemenkes P, Gizi J, Kemenkes P Kebidanan $\mathrm{J}$, et al. Manfaat media flipchart dan spanduk dalam perilaku kesehatan 1000 HPK di Sulawesi Tengah the benefits of flipchart media and banner toward health behavior the first 1000 days of life in central Sulawesi. Jurnal MIKMI. 2016;14(1)52-60. https://doi.org/10.30597/mkmi.v14i1.1870

29. Efevbera Y, Bhabha J, Farmer PE, Fink G. Girl child marriage as a risk factor for early childhood development and stunting Soc Sci Med. 2017;185:91-101. https://doi.org/10.1016/j. socscimed.2017.05.027 PMid:28570927

30. Pangaribuan IK, Sari I, Simbolon M, Manurung B, Ramuni K. Relationship between early marriage and teenager pregnancy to stunting in toddler at Bangun Rejo Village, Tanjung Morawa District, Tanjung Morawa, Deli Serdang 2019. Enferm Clín. 2020;30(5):88-91. https://doi.org/10.1016/j.enfcli.2019.11.028

31. Berhe K, Seid O, Gebremariam Y, BerheA, Etsay N. Risk factors of stunting (chronic undernutrition) of children aged 6 to 24 months in Mekelle City, Tigray Region, North Ethiopia: An unmatched case-control study. PLoS One. 2019;14(6):e0217736. https:// doi.org/10.1371/journal.pone.0217736 PMid:31181094

32. Li Z, Kim R, Vollmer S, Subramanian SV. Factors associated with child stunting, wasting, and underweight in 35 low-and middleincome countries. JAMA Netw Open. 2020;3(4):e203386. https://doi.org/10.1001/jamanetworkopen.2020.3386 PMid:32320037

33. Yunitasari E, Nadhifah WP. The effects of health education on increasing knowledge, attitudes, and stunting prevention in premarriage couples in bangkalan madura. Eur Asian J Biosci. 2020;14(1):2519-25.

34. Fitriani F, Farisni TN, Syahputri VN, Lestary LA, Helmyati S. Implementing precede-proceed model toward the mothers perception on the importance of feeding of home-made complementary food to wasting and stunting toddlers. Curr Res Nutr Food Sci J. 2020;8(2):489-95. https://doi.org/10.12944/ crnfsj.8.2.14

35. Yunitasari E, Rahayu MK. The effects of lecture, brainstorming demonstration (CBD) to mother's knowledge, attitude, and behavior about stunting prevention on toddler. Syst Rev Pharm. 2020;11(6):1131-6.

36. Sumbele IU, Asoba GN, Teh RN, Metuge S, Anchang-Kimbi JK Nkuo-Akenji T. Burden of moderate to severe anaemia and severe stunting in children $<3$ years in conflict-hit Mount Cameroon: A community based descriptive cross-sectional study. BMC Pediatr. 2020;20(1):396. https://doi.org/10.1186/ s12887-020-02296-2

PMid:32838765

37. Nachvak SM, Sadeghi O, Moradi S, Esmailzadeh A, Mostafai R. Food groups intake in relation to stunting among exceptional children. BMC Pediatr. 2020;20(1):394. https://doi.org/10.1186/ s12887-020-02291-7 PMid:32819323

38. Arini D, Nursalam N, Mahmudah M, Faradilah I. The incidence of stunting, the frequency/duration of diarrhea and acute respiratory infection in toddlers. J Public Health Res. 2020;9(2):117-20. https://doi.org/10.4081/jphr.2020.1816 PMid:32728562

39. González Acero C, Martinez S, Pérez-Expósito A, Winters S. Effect of an innovative behavioural change strategy and smallquantity lipid-based nutrient supplements on stunting and obesity in children in Baja Verapaz, Guatemala: Protocol for a randomised control trial. BMJ Open. 2020;10(7):e035528. https://doi.org/10.1136/bmjopen-2019-035528

40. Faisal E, Hafid F, Kusumawati DE, Nasrul N, Jurana J. The implementation of infant and young children feeding counseling Open Access Maced J Med Sci. 2021;9:224-8. https://doi. org/10.3889/oamjms.2021.5882 